\title{
EFFICIENCY OF NATURAL LIGHTING IN OFFICE BUILDINGS ON THE EXAMPLE OF A BUILDING LOCATED IN POLAND
}

\section{EFEKTYWNOŚĆ NATURALNEGO OŚWIETLENIA BUDYNKÓW BIUROWYCH NA PRZYKŁADZIE OBIEKTU ZLOKALIZOWANEGO W POLSCE}

\author{
Rafał Lichołai \\ mgr inż. arch. \\ Author's Orcid number: 0000-0002-0904-7812 \\ Rzeszów University of Technology, Rzeszów, Poland \\ The Faculty of Civil and Environmental Engineering and Architecture \\ Department of Building Conservation
}

\begin{abstract}
It is important for sustainability to reduce the energy demand of both existing and planned buildings. The requirements for workspace lighting clearly define the minimum light intensity that must be provided. The aim of the study was to verify if the selected office layouts independently fulfill the requirements of the Polish Norm for lighting of workplaces without the use of artificial light sources. The analysis took into consideration standard working hours of office buildings, that is from January to December, from 8 a.m. to 4 p.m. Interpretation of the obtained data allowed to select the layouts that maintain the most stable efficiency of natural daylight.
\end{abstract}

Key words: architecture, insolation, office buildings, efficiency.

\section{STRESZCZENIE}

Istotne z punktu widzenia zrównoważonego rozwoju jest ograniczenie zapotrzebowania energii zarówno istniejących jak i projektowanych budynków. Wymagania dotyczące oświetlenia przestrzeni przeznaczonej do pracy precyzyjnie określają minimalne natężenie światła, jakie musi być zapewnione. Celem niniejszej pracy jest weryfikacja czy wybrane układy biurowe spełniają wymagania Polskiej Normy dotyczącej oświetlenia miejsc pracy bez konieczności stosowania sztucznych źródeł światła. W analizie wzięto pod uwagę standardowy czas pracy obiektów biurowych tj. od stycznia do grudnia w godzinach od 8 do 16. Interpretacja uzyskanych wyników umożliwiła wytypowanie układów, które wykazują najbardziej stabilną efektywność nasłonecznienia naturalnego.

Słowa kluczowe: architektura, nasłonecznienie, budynki biurowe, efektywność. 


\section{INTRODUCTION}

Modern concepts of building design aim to reduce the negative impact of the implementation of these investments on the environment. In 2018, the European Commission published a long-term strategy to achieve climate neutrality (Komisja Europejska, 2018). In the literature on this subject we can find a clear division of ways to reduce the negative impact on the environment, that is, active and passive. The first group includes such solutions as heat pumps (Kimata S., Shina T., Sato T., Tokoro K., 2020.), while an example of a solution belonging to the second category can be e.g. window shading systems (Kunwar N., Bhandari M., 2020).

The energy demand of a building depends mainly on the location, climate, season and use of the building, while energy itself is used for ventilation, heating, cooling and lighting among others (Sassi P., 2006, p. 205). A report by Knight Frank based on data obtained from 2011-2018 showed that utility consumption in commercial buildings consumes $37 \%$ of the total operating costs (Knight Frank, 2019, p. 5), making it important from a sustainability standpoint to look for effective ways to minimize the energy needed for both economic and environmental reasons.

The quality of natural lighting was studied by e.g. Dariusz Masły and Michał Sitek (Masły D., Sitek M., 2013.). In their study, the authors examined the impact of façade solutions on the intensity of daylight, taking into account the effect of space overheating. Contemporary research trends largely oscillate around the development of ways to increase the amount of natural lighting. The idea of using atrium as an additional illuminating source has been investigated by numerous research teams (Rastegari M., Pournaseri S., Sanaieian H., 2021., Fan Z., Yang Z., Yang L., 2021., Ferreira T, Bournas I, Dubois M-C, 2019., Susa-Páez A., Piderit-Moreno M. B., 2020. ), but such a solution is practically applicable only in the case of designing new buildings. There are also studies that use artificial neural networks to predict natural lighting inside a building (Walger da Fonseca R., Didoné E. L., Pereira F. O. R., 2013.)

One of the most important decisions when designing an office space is to determine how to provide light. Both natural and artificial lighting should be assured. The essence of the issue is to design glazing in the most effective way, taking into account such parameters as the amount of natural light access, limitation of overheating of interiors and economic efficiency of the applied solutions. The methods of natural lighting may include interference in the body of the building, e.g. through the use of a glazed atrium or ad hoc solutions such as the light shelves.

Despite the existence of individual ways to increase the amount of natural light, there is a lack of conclusive research results to determine the effectiveness of natural sunlight within office layouts located in Poland. In this study, therefore, an iterative analysis was carried out, whose main objective was to verify the possibility of using office layouts without artificial light sources. The interpretation of the results obtained will improve the design process in terms of estimating the need for additional light sources. Data on the effectiveness of natural lighting can be used in the design of new buildings, or when assessing the possibility of using existing buildings for office purposes.

\section{EVOLUTION OF OFFICE SPACES}

Elżbieta Niezabitowska divided the history of the development of office buildings into six major periods (Niezabitowska E., 1997, p. 42). The author identifies the first period with the existence of the so-called Buleuterion in ancient Greece, which later served as a prototype for medieval town halls. The next period refers to the time from the creation of the first medieval Italian town hall until the 19th century, when administrative functions were separated from judicial and banking ones. The third period refers to the so-called Chicago School in the second half of the 19th century. The next period lasted until the 1950s, in which large-scale office buildings developed. In the fifth stage the characteristic treatment used was landscape solution of office buildings' interiors. The last stage began in the 1970s, which saw an increased demand for so-called highly skilled office work with the introduction of computers into office spaces.

A breakthrough in the design of office buildings is associated with the increasingly used solution of buildings with a frame structure. One of the buildings, whose function and form can be associated 
with modern office solutions was The Home Insurance Building built in 1885 (Moon K. S., 2018, p. 2). The concept of F.W. Taylor's theory of work organization assuming increasing the efficiency of work by, i. a., dividing work into stages, motivating employees with financial incentives, or eliminating distracting elements was included in the realization of Larkin Building from 1904 by Frank Lloyd Wright (Urbanowicz B., 2011, p. 55). The building was designed as a co-designed space with desks for employees arranged in a short-distance array, while managers were provided with individual rooms arranged along the interior walls. The development of such a layout can be found in contemporary projects.

Adam Dzidowski, while characterizing the changes in office space, pointed out the change in the formation of approaches to work organization (Dzidowski A., 2015, p.159). The author detailed five concepts, influencing the change of office spaces. The first "Taylorism" implied paying special attention to, among other issues, economy of movement, efficiency and systematic work. "Bürolandschaf" occurring in the second half of the 20th century took into account freedom and privacy while emphasizing the need for mechanization and systemization of work. "Action Office" dated by the author to 1968 was characterized by a desire to use modular cubic forms to separate space. "Cube Farm" occurring around 1980 was a development of the earlier form with a change in the function of cubic forms, which in this concept had a disciplinary function. The last system of work mentioned by the researcher he described as "Networking", which focuses on mobility and computerization.

Maciej Złowodzki in his publication from 2008 characterized Polish office buildings market (Złowodzki M., 2008, p.75-77). The author focused particular attention on the problems of solutions, both at the architectural and urban planning level, of buildings with office functions, such as spatial disorder or standards that differ from identical buildings in Western Europe. The researcher points out the lack of coherent research programs and lack of learning experiences from other countries.

\section{RESEARCH METHODOLOGY}

According to the current standard specifying the lighting conditions for workplaces such as conference rooms, meeting rooms and CAD workstations the minimum illuminance is 500 Ix (PN-EN 12464-1, p.30). Interior lighting analysis methods can be divided into two main approaches. The first one is based on the use of real data obtained from physically distributed sensors that record light intensity levels and their changes over time, which forms the basis for a model. The second method, used in this paper, involves predicting light intensity levels under specific conditions using computer simulation. The research model was prepared using Rhino software with Grasshopper overlay for parametric modeling. In order to perform simulations allowing to determine the intensity of natural light for the assumed geometries, Honeybee add-on based on results obtained from Daysim software was used. (Fig.1).

The efficiency of natural lighting of the floors of an office building realized in a linear arrangement according to the typology proposed by Anna Taczalska (Taczalska A., 2016, p. 27) was studied. For the purpose of simulation, the standard working time of office buildings was assumed, from January to December from 8 am to $4 \mathrm{pm}$.

In order to compare the relationship between storey height and depth, the iterative algorithm Colibri 1.0 was used. Based on the standard construction solutions in the building, the following variable values were assumed for the studied simulation (Fig. 2):

- storey height in the range $3.0 \mathrm{~m}$ to $5.0 \mathrm{~m}$,

- depth of storey from $5.0 \mathrm{~m}$ to $9.0 \mathrm{~m}$.

The data obtained has been divided into individual months for the assumed location - Warsaw. Full glazing of external partitions was assumed in the simulation. The research area was divided into squares of $1 \mathrm{~m}$ side. The summary results obtained are presented in Figure. 3. 

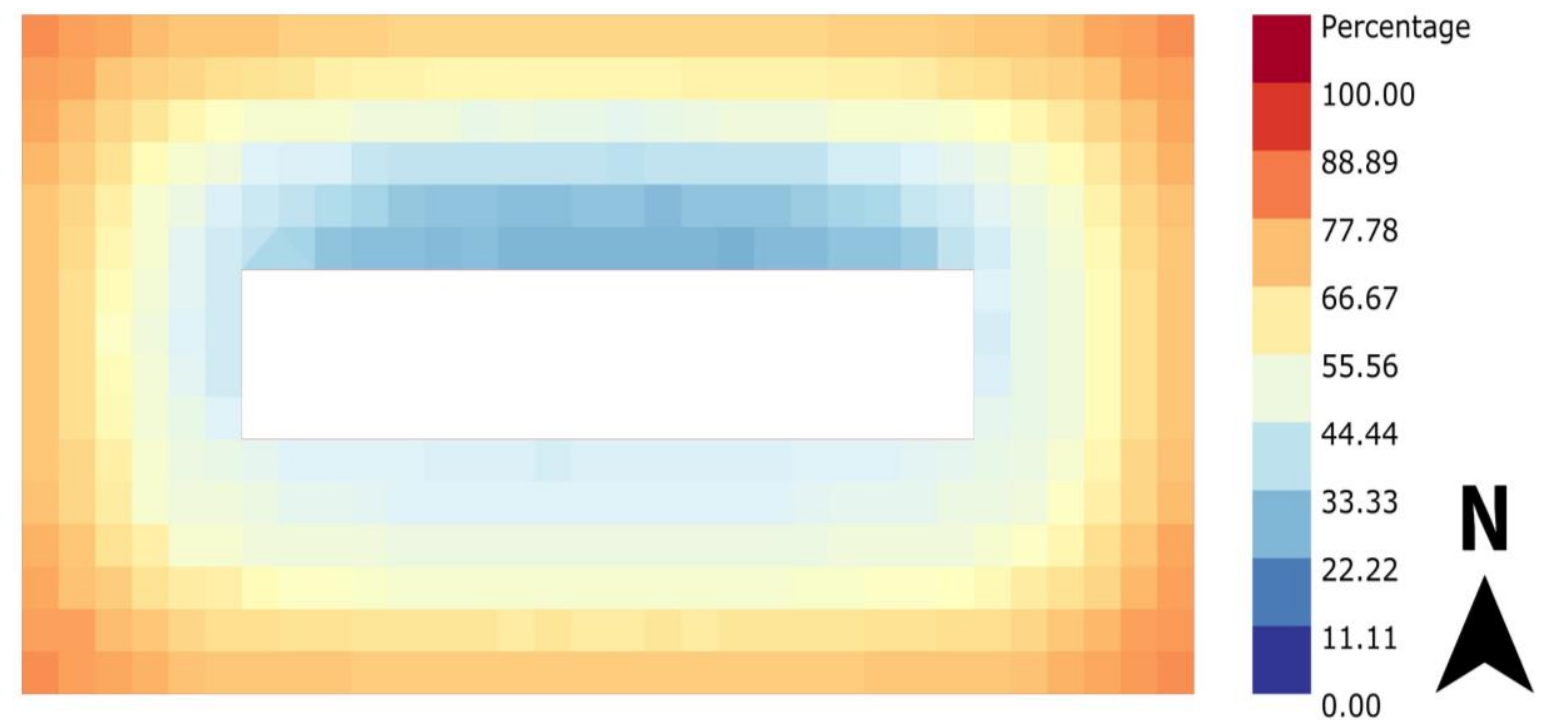

Fig. 1 Annual percent insolation results for a layout with parameters $H=3.5 \mathrm{~m}$ and $\mathrm{D}=7.0 \mathrm{~m}$ obtained in Grasshopper with Daysim software The results show the percentage insolation time of one $1 \times 1 \mathrm{~m}]$ field with a minimum intensity of $500 \mathrm{Ix}$ during the hours of the analysis. Source: Original work, 2021

Ryc. 1 Roczne wyniki procentowego nasłonecznienia dla układu o parametrach $\mathrm{H}=3.5 \mathrm{~m}$ i $\mathrm{D}=7.0 \mathrm{~m}$ uzyskane w oprogramowaniu Grasshopper z dodatkiem Daysim. Otrzymane rezultaty przedstawiają procentowy czas nasłonecznienia jednego pola o wymiarach $1 \times 1$ [m] o natężeniu minimum $500 \mathrm{~lx}$ w przyjętych dla analizy godzinach.

Źródło: Opracowanie autora 2021

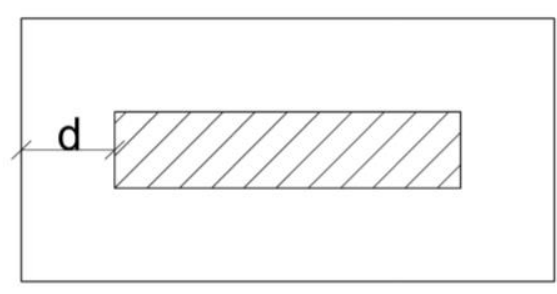

\section{FLOOR PLAN}

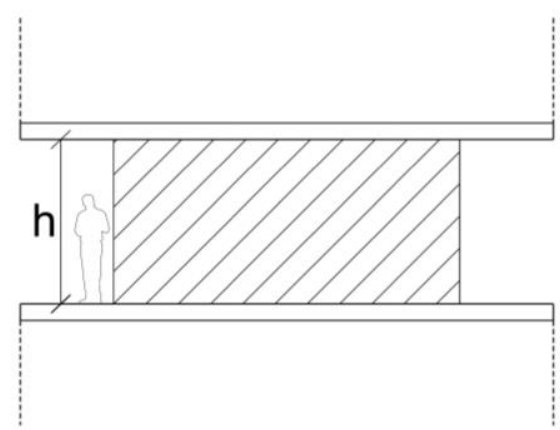

\section{SECTION}

Fig. 2 The studied range of variable values of storey height $(H)$, and depth $(D)$ expressed in meters. Source: Original work, 2021

Ryc. 2 Przyjęty zakres zmiennych wartości wysokości kondygnacji $(H)$, oraz głębokości (D) wyrażony w metrach. Źródło: Opracowanie autora, 2021

\begin{tabular}{|c|c|c|c|c|c|c|}
\hline Lp. & $H[\mathrm{~m}]$ & $\mathrm{D}[\mathrm{m}]$ & \multicolumn{2}{l|}{$\mathrm{L} . \mathrm{H}[\mathrm{m}]$} & $\mathrm{D}[\mathrm{m}]$ \\
\hline 1 & 3.0 & 5.0 & 14 & 4.5 & 7.0 \\
\hline 2 & 3.5 & 5.0 & 15 & 5.0 & 7.0 \\
\hline 3 & 4.0 & 5.0 & 16 & 3.0 & 8.0 \\
\hline 4 & 4.5 & 5.0 & 17 & 3.5 & 8.0 \\
\hline 5 & 5.0 & 5.0 & 18 & 4.0 & 8.0 \\
\hline 6 & 3.0 & 6.0 & 19 & 4.5 & 8.0 \\
\hline 7 & 3.5 & 6.0 & 20 & 5.0 & 8.0 \\
\hline 8 & 4.0 & 6.0 & 21 & 3.0 & 9.0 \\
\hline 9 & 4.5 & 6.0 & 22 & 3.5 & 9.0 \\
\hline 10 & 5.0 & 6.0 & 23 & 4.0 & 9.0 \\
\hline 11 & 3.0 & 7.0 & 24 & 4.5 & 9.0 \\
\hline 12 & 3.5 & 7.0 & 25 & 5.0 & 9.0 \\
\hline 13 & 4.0 & 7.0 & & & \\
\hline & & & & & \\
\hline
\end{tabular}




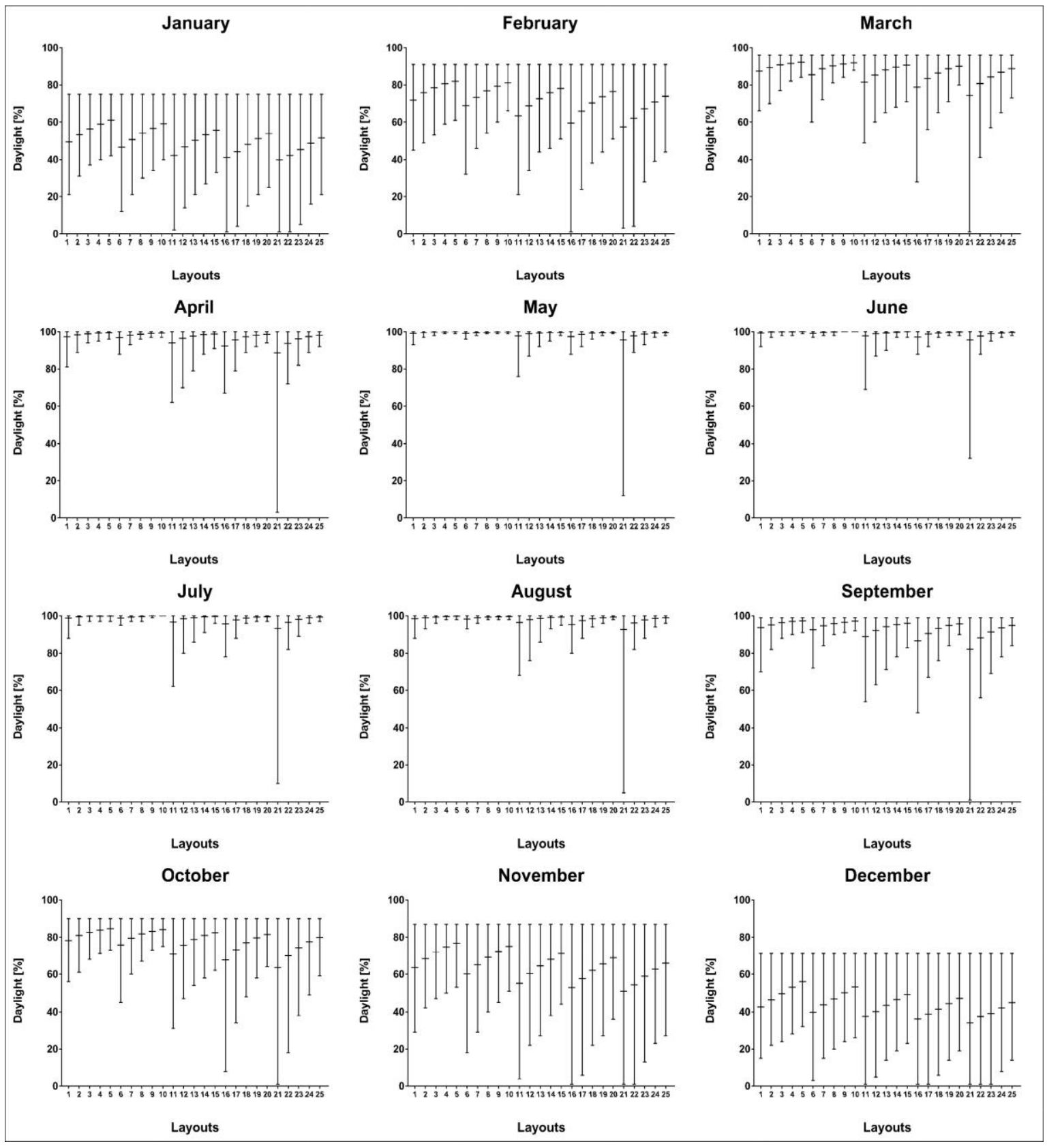

Fig. 3 Obtained simulation results of 25 systems, presented by month study. The graphs show the layouts studied (horizontal axis), with the percentage of fields providing a minimum of $500 \mathrm{Ix}$ throughout the adopted test range (vertical axis). Source: Original work, 2021

Ryc. 3 Uzyskane wyniki symulacji 25 układów, przedstawione z podziałem na badanie miesiące. Na wykresach przedstawiono badane układy (pozioma oś), z określeniem w procentach pól zapewniających minimum 500 Ix przez cały przyjęty zakres badania (pionowa oś). Żródło: Opracowanie autora, 2021

\section{RESULTS OBTAINED}

In the conducted study, different grid divisions were obtained due to the value of the storey depth parameter. The division was 363 fields for $5.0 \mathrm{~m}, 433$ fields for $6.0 \mathrm{~m}, 553$ fields for $7.0 \mathrm{~m}, 643$ fields for $8.0 \mathrm{~m}, 757$ fields for $9.0 \mathrm{~m}$. In order to facilitate the interpretation of the results obtained, a sum- 
mary table was prepared, showing the number of fields that receive an intensity of $500 \mathrm{Ix}$ throughout the assumed research period expressed in percentage, the value of the mean (marked with an "X") and variance (marked with a "s") for each tested system in a given month (Tab.1).

\section{No. 5}
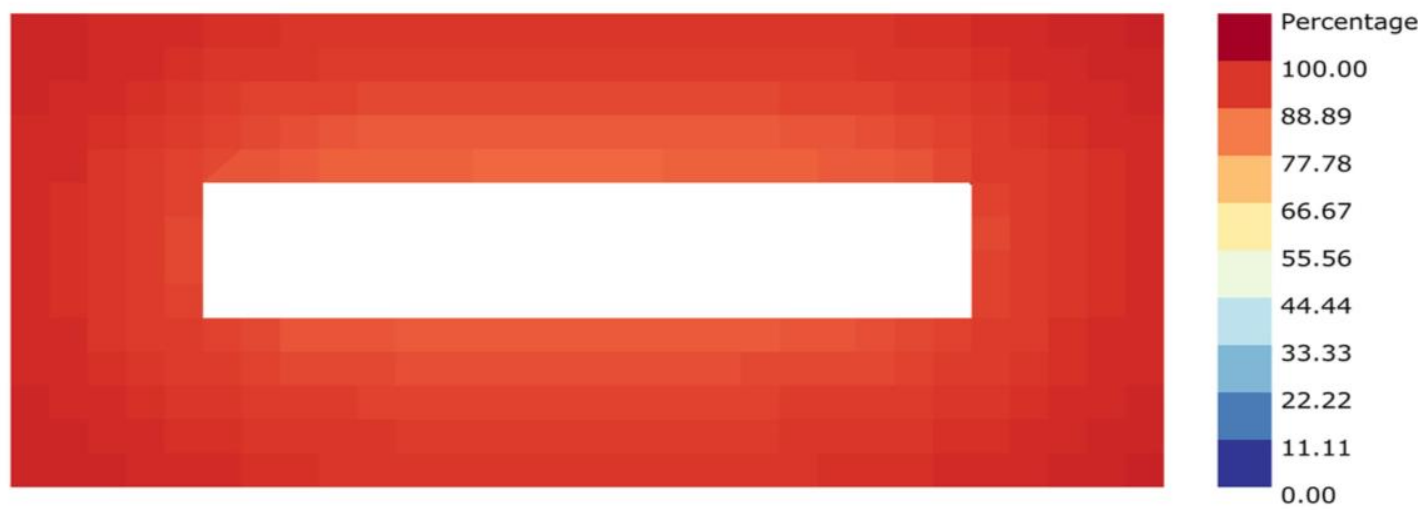

No. 21
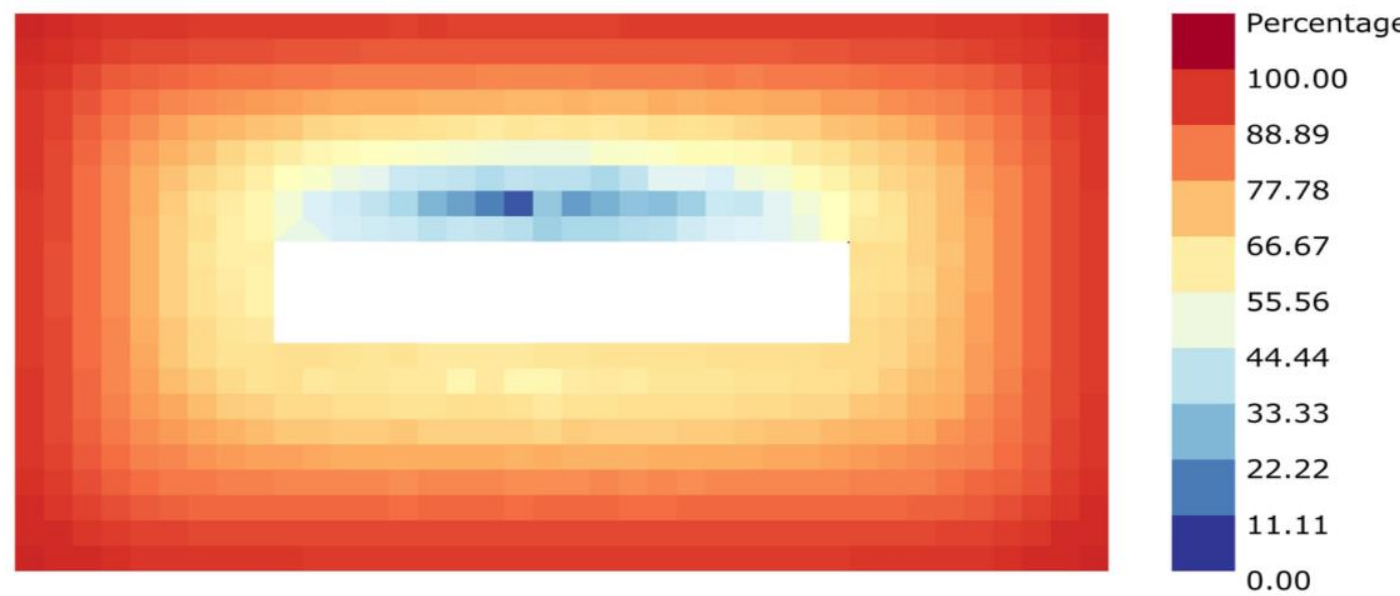

Fig. 4 Summary of the annual insolation of the best (number 5) and worst (number 21) layouts within the range studied. The results show the percentage insolation time of one $1 \times 1[\mathrm{~m}]$ field with a minimum intensity of $500 \mathrm{Ix}$ during the hours of the analysis. Source: Original work, 2021

Ryc. 4 Zestawienie rocznego nasłonecznienia najlepszego (numer 5) i najgorszego (numer 21 układy w ramach badanego zakresu. Otrzymane rezultaty przedstawiają procentowy czas nasłonecznienia jednego pola o wymiarach $1 \times 1$ [m] o natężeniu minimum 500 Ix w przyjętych dla analizy godzinach. Źródło: Opracowanie autora, 2021

Interpreting the parameter that determines the number of fields receiving the required light intensity value specified by PN-EN 12464-1 it is concluded that none of the analysed systems during the year provides the required illumination using natural light sources. The best results were obtained in the month of June for systems 9 and 10 and in July for system 10, in which a minimum of $500 \mathrm{Ix}$ was obtained throughout the month from 8 a.m. to 4 p.m. The least optimal results in terms of the percentage time to ensure the minimum value of light intensity were obtained by layouts 16 and 21 . The smallest and, at the same time, most similar values of variance are found in layouts 3-5 and 810 , while the largest mean values, in which the smallest fluctuations of readings within the examined year occur in layouts 5 and 10, which leads to the conclusion that out of all the examined vari- 
ants, number 5 and 10 are the most optimal in terms of the amount of natural insolation. The highest values of variance were obtained for layouts 16-17 and 21-22, while the lowest values of mean variance can be found for layouts 16 and 21 , which are the most unfavourable variants. The best results were obtained for height and depth parameters of $5.0 \mathrm{~m}$ to $5.0 \mathrm{~m}$ and $5.0 \mathrm{~m}$ to $6.0 \mathrm{~m}$, while the most unfavorable results were obtained for height and depth values of $3.0 \mathrm{~m}$ to $8.0 \mathrm{~m}$ and $3.0 \mathrm{~m}$ to $9.0 \mathrm{~m}$ (Fig. 4). Equally important information is the complete lack of fields fulfilling the assumed condition in the months from January to March and from September to December resulting from the adopted location, which translates into the necessity of providing additional artificial lighting in office buildings located in Poland, assuming that such buildings are used all year round.

Table 1. Summary of the results obtained with the percentage (marked with a "\%") of fields fulfilling the assumed conditions, variance (marked with a "s") and mean (marked with an "X") . Source: Original work, 2021.

Tabela 1. Zestawienie uzyskanych wyników z określeniem procentowej ilości pól spełniających zakładane warunki (oznaczenie symbolem „\%”), wariancji (oznaczenie symbolem „\$2") i średniej (oznaczenie symbolem „X”). Źródło: Opracowanie autora, 2021.

\begin{tabular}{|c|c|c|c|c|c|c|c|c|c|c|c|c|c|}
\hline \multirow[t]{2}{*}{ No, } & \multirow[t]{2}{*}{ Result } & \multicolumn{12}{|c|}{ MONTHS } \\
\hline & & 1 & II & III & IV & V & VI & VII & VIII & IX & $x$ & $X I$ & XII \\
\hline 1 & $\%$ & $0 \%$ & $0 \%$ & $0 \%$ & $33 \%$ & $52 \%$ & $74 \%$ & $68 \%$ & $47 \%$ & $0 \%$ & $0 \%$ & $0 \%$ & $0 \%$ \\
\hline 1 & $s^{2}$ & 178 & 161,7 & 49,2 & 13,3 & 2,2 & 2,8 & 6,2 & 5,8 & 32,2 & 73,5 & 240,4 & 239,1 \\
\hline 1 & $x$ & 49,5 & 71,9 & 87,5 & 97,3 & 99,2 & 99,2 & 98,7 & 98,4 & 93,7 & 78,2 & 63,6 & 42,5 \\
\hline 2 & $\%$ & $0 \%$ & $0 \%$ & $0 \%$ & $40 \%$ & $67 \%$ & $89 \%$ & $82 \%$ & $54 \%$ & $0 \%$ & $0 \%$ & $0 \%$ & $0 \%$ \\
\hline 2 & $s^{2}$ & 134 & 101,6 & 28,5 & 5,1 & 0,5 & 0,5 & 1,4 & 1,8 & 15,2 & 40,4 & 165,8 & 215,3 \\
\hline 2 & $x$ & 53,2 & 75,8 & 89,5 & 98,4 & 99,6 & 99,8 & 99,5 & 99,1 & 95,1 & 80,9 & 68,3 & 46,3 \\
\hline 3 & $\%$ & $0 \%$ & $0 \%$ & $0 \%$ & $52 \%$ & $75 \%$ & $94 \%$ & $94 \%$ & $63 \%$ & $0 \%$ & $0 \%$ & $0 \%$ & $0 \%$ \\
\hline 3 & $s^{2}$ & 110 & 71,1 & 12,3 & 2,5 & 0,3 & 0,2 & 0,5 & 1,1 & 6,6 & 23,3 & 117,1 & 199,4 \\
\hline 3 & $x$ & 56,2 & 78,5 & 90,8 & 98,9 & 99,7 & 99,9 & 99,8 & 99,3 & 96,4 & 82,7 & 71,9 & 49,7 \\
\hline 4 & $\%$ & $0 \%$ & $0 \%$ & $0 \%$ & $58 \%$ & $87 \%$ & $95 \%$ & $94 \%$ & $75 \%$ & $0 \%$ & $0 \%$ & $0 \%$ & $0 \%$ \\
\hline 4 & $s^{2}$ & 88,2 & 44,3 & 8,2 & 1,3 & 0,1 & 0,2 & 0,4 & 0,4 & 4,4 & 15,3 & 83,1 & 171,0 \\
\hline 4 & $x$ & 58,9 & 80,5 & 91,6 & 99,3 & 99,9 & 99,9 & 99,8 & 99,7 & 97,0 & 83,8 & 74,7 & 52,9 \\
\hline 5 & $\%$ & $0 \%$ & $0 \%$ & $0 \%$ & $66 \%$ & $94 \%$ & $98 \%$ & $95 \%$ & $85 \%$ & $0 \%$ & $0 \%$ & $0 \%$ & $0 \%$ \\
\hline 5 & $\mathrm{~s}^{2}$ & 72,6 & 33,3 & 5,8 & 0,7 & 0,1 & 0,0 & 0,3 & 0,3 & 3,3 & 10,9 & 61,6 & 143,4 \\
\hline 5 & $x$ & 61,0 & 81,9 & 92,2 & 99,5 & 99,9 & 100,0 & 99,9 & 99,8 & 97,4 & 84,6 & 76,8 & 56,0 \\
\hline 6 & $\%$ & $0 \%$ & $0 \%$ & $0 \%$ & $29 \%$ & $46 \%$ & $66 \%$ & $61 \%$ & $43 \%$ & $0 \%$ & $0 \%$ & $0 \%$ & $0 \%$ \\
\hline 6 & $\mathrm{~s}^{2}$ & 231, & 220,3 & 73,7 & 11,6 & 1,0 & 1,4 & 2,8 & 3,7 & 37,6 & 116,1 & 322,3 & 286,6 \\
\hline 6 & $x$ & 46,6 & 68,8 & 85,6 & 96,8 & 99,2 & 99,2 & 98,7 & 98,3 & 92,6 & 75,8 & 60,2 & 39,8 \\
\hline 7 & $\%$ & $0 \%$ & $0 \%$ & $0 \%$ & $35 \%$ & $56 \%$ & $81 \%$ & $70 \%$ & $49 \%$ & $0 \%$ & $0 \%$ & $0 \%$ & $0 \%$ \\
\hline 7 & $\mathrm{~s}^{2}$ & 169 & 134,5 & 26,9 & 4,1 & 0,4 & 0,6 & 1,4 & 1,5 & 12,8 & 51,8 & 231,7 & 242,7 \\
\hline 7 & $x$ & 50,7 & 73,4 & 88,7 & 98,1 & 99,5 & 99,6 & 99,3 & 99,0 & 94,7 & 79,5 & 65,0 & 43,7 \\
\hline 8 & $\%$ & $0 \%$ & $0 \%$ & $0 \%$ & $46 \%$ & $67 \%$ & $92 \%$ & $84 \%$ & $56 \%$ & $0 \%$ & $0 \%$ & $0 \%$ & $0 \%$ \\
\hline 8 & $s^{2}$ & 131 & 78,7 & 12,8 & 2,2 & 0,2 & 0,3 & 0,9 & 0,8 & 8,1 & 26,4 & 158,8 & 223,6 \\
\hline 8 & $x$ & 54,0 & 76,9 & 90,2 & 98,7 & 99,7 & 99,9 & 99,6 & 99,3 & 95,8 & 81,8 & 69,2 & 46,9 \\
\hline 9 & $\%$ & $0 \%$ & $0 \%$ & $0 \%$ & $52 \%$ & $76 \%$ & $100 \%$ & $94 \%$ & $67 \%$ & $0 \%$ & $0 \%$ & $0 \%$ & $0 \%$ \\
\hline 9 & $s^{2}$ & 107 & 49,9 & 6,9 & 1,2 & 0,2 & 0,0 & 0,1 & 0,6 & 5,3 & 15,3 & 111,1 & 201,7 \\
\hline 9 & $x$ & 56,6 & 79,3 & 91,3 & 99,1 & 99,8 & 100,0 & 99,9 & 99,5 & 96,5 & 83,2 & 72,3 & 50,1 \\
\hline 10 & $\%$ & $0 \%$ & $0 \%$ & $0 \%$ & $58 \%$ & $85 \%$ & $100 \%$ & $100 \%$ & $75 \%$ & $0 \%$ & $0 \%$ & $0 \%$ & $0 \%$ \\
\hline 10 & $\mathrm{~s}^{2}$ & 85,2 & 28,4 & 4,6 & 1,0 & 0,1 & 0,0 & 0,0 & 0,4 & 2,8 & 9,4 & 68,1 & 177,1 \\
\hline
\end{tabular}




\begin{tabular}{|c|c|c|c|c|c|c|c|c|c|c|c|c|c|}
\hline \multirow{2}{*}{$\begin{array}{l}\text { No, } \\
10 \\
\end{array}$} & \multirow{2}{*}{$\begin{array}{c}\text { Result } \\
\mathrm{X} \\
\end{array}$} & \multicolumn{12}{|c|}{ MONTHS } \\
\hline & & 59,0 & 81,1 & 91,9 & \begin{tabular}{|l|}
99,3 \\
\end{tabular} & 99,9 & 100,0 & 100,0 & 99,7 & 97,2 & 84,2 & 75,1 & 53,1 \\
\hline 11 & $\%$ & $0 \%$ & $0 \%$ & $0 \%$ & $24 \%$ & $39 \%$ & $55 \%$ & $52 \%$ & $37 \%$ & $0 \%$ & $0 \%$ & $0 \%$ & $0 \%$ \\
\hline 11 & $\mathrm{~s}^{2}$ & 308, & 344,7 & 153 & 53,3 & 14,2 & 17,7 & 31,7 & 25,8 & 105,6 & 239,1 & 438,1 & 264,8 \\
\hline 11 & $x$ & 42,3 & 63,4 & 81,4 & 94,1 & 97,8 & 97,8 & 96,7 & 96,4 & 88,9 & 70,8 & 55,0 & 37,4 \\
\hline 12 & $\%$ & $0 \%$ & $0 \%$ & $0 \%$ & $30 \%$ & $47 \%$ & $68 \%$ & $59 \%$ & $40 \%$ & $0 \%$ & $0 \%$ & $0 \%$ & $0 \%$ \\
\hline 12 & $\mathrm{~s}^{2}$ & 221, & 226,3 & 80,2 & 22,5 & 3,1 & 4,1 & 8,9 & 9,6 & 47,5 & 121,3 & 313,6 & 276,3 \\
\hline 12 & $x$ & 46,8 & 68,7 & 85,4 & 96,5 & 99,0 & 99,0 & 98,4 & 98,0 & 92,2 & 75,7 & 60,4 & 40,1 \\
\hline 13 & $\%$ & $0 \%$ & $0 \%$ & $0 \%$ & $38 \%$ & $56 \%$ & $76 \%$ & $70 \%$ & $46 \%$ & $0 \%$ & $0 \%$ & $0 \%$ & $0 \%$ \\
\hline 13 & $\mathrm{~s}^{2}$ & 180,0 & 155,5 & 38,9 & 10,57 & 1,43 & 1,95 & 4,34 & 3,97 & 23,50 & 66,83 & 244,3 & 243,8 \\
\hline 13 & $x$ & 50,24 & 72,65 & 88,0 & 97,66 & 99,3 & 99,4 & 98,9 & 98,63 & \begin{tabular}{|l|l}
94,22 \\
\end{tabular} & 78,83 & 64,42 & 43,43 \\
\hline 14 & $\%$ & $0 \%$ & $0 \%$ & $0 \%$ & $43 \%$ & $62 \%$ & $86 \%$ & $80 \%$ & $56 \%$ & $0 \%$ & $0 \%$ & $0 \%$ & $0 \%$ \\
\hline 14 & $\mathrm{~s}^{2}$ & 144,4 & 102,5 & 23,0 & 4,42 & 0,61 & 0,54 & 1,77 & 1,47 & 14,12 & 40,64 & 181,4 & 226,5 \\
\hline 14 & $x$ & 53,23 & 75,87 & 89,5 & 98,40 & 99,5 & 99,7 & 99,4 & 99,16 & \begin{tabular}{|l|}
95,27 \\
\end{tabular} & 80,97 & 67,98 & 46,50 \\
\hline 15 & $\%$ & $0 \%$ & $0 \%$ & $0 \%$ & $47 \%$ & $73 \%$ & $98 \%$ & $87 \%$ & $61 \%$ & $0 \%$ & $0 \%$ & $0 \%$ & $0 \%$ \\
\hline 15 & $\mathrm{~s}^{2}$ & 120,6 & 73,86 & 14,0 & 2,60 & 0,26 & 0,14 & 0,63 & 0,98 & 8,78 & 25,08 & 134,1 & 210,2 \\
\hline 15 & $x$ & 55,61 & 78,06 & 90,6 & 98,84 & 99,7 & 99,9 & 99,7 & 99,33 & 96,05 & 82,42 & 71,09 & 49,16 \\
\hline 16 & $\%$ & $0 \%$ & $0 \%$ & $0 \%$ & $21 \%$ & $36 \%$ & $51 \%$ & $49 \%$ & $34 \%$ & $0 \%$ & $0 \%$ & $0 \%$ & $0 \%$ \\
\hline 16 & $\mathrm{~s}^{2}$ & 296,1 & 503,4 & 232 & 75,22 & 11,0 & 16,0 & 34,9 & 32,18 & \begin{tabular}{|l}
157,1 \\
\end{tabular} & 353,9 & 467,6 & 256,0 \\
\hline 16 & $x$ & 41,01 & 59,50 & 78,7 & 92,42 & 97,4 & 97,1 & 95,7 & 95,39 & 86,56 & 67,59 & 52,73 & 36,05 \\
\hline 17 & $\%$ & $0 \%$ & $0 \%$ & $0 \%$ & $26 \%$ & $43 \%$ & $61 \%$ & $54 \%$ & $36 \%$ & $0 \%$ & $0 \%$ & $0 \%$ & $0 \%$ \\
\hline 17 & $\mathrm{~s}^{2}$ & 282,4 & 300,6 & 117 & 25,00 & 3,48 & 3,28 & 10,1 & 9,79 & 70,93 & 185,9 & 389,1 & 270,8 \\
\hline 17 & $x$ & 44,19 & 65,79 & 83,3 & 95,64 & 98,5 & 98,7 & 97,7 & 97,44 & 90,64 & 73,19 & 57,55 & 38,80 \\
\hline 18 & $\%$ & $0 \%$ & $0 \%$ & $0 \%$ & $35 \%$ & $51 \%$ & $69 \%$ & $64 \%$ & $43 \%$ & $0 \%$ & $0 \%$ & $0 \%$ & $0 \%$ \\
\hline 18 & $\mathrm{~s}^{2}$ & 214,0 & 198,2 & 60,4 & 9,48 & 0,82 & 1,19 & 2,44 & 2,98 & 29,57 & 98,76 & 297,9 & 270,5 \\
\hline 18 & $x$ & 48,12 & 70,33 & 86,5 & 97,26 & 99,2 & 99,2 & 98,8 & 98,47 & 93,25 & 77,00 & 61,94 & 41,33 \\
\hline 19 & $\%$ & $0 \%$ & $0 \%$ & $0 \%$ & $38 \%$ & $57 \%$ & $80 \%$ & $72 \%$ & $51 \%$ & $0 \%$ & $0 \%$ & $0 \%$ & $0 \%$ \\
\hline 19 & $\mathrm{~s}^{2}$ & 172,3 & 137,7 & 27,6 & 4,22 & 0,42 & 0,61 & 1,48 & 1,61 & \begin{tabular}{|l|}
13,37 \\
\end{tabular} & 53,22 & 230,7 & 244,6 \\
\hline 19 & $x$ & 51,18 & 73,72 & 88,7 & 98,11 & 99,4 & 99,6 & 99,2 & 98,95 & 94,81 & 79,69 & 65,47 & 44,35 \\
\hline 20 & $\%$ & $0 \%$ & $0 \%$ & $0 \%$ & $43 \%$ & $66 \%$ & $90 \%$ & $82 \%$ & $56 \%$ & $0 \%$ & $0 \%$ & $0 \%$ & $0 \%$ \\
\hline 20 & $\mathrm{~s}^{2}$ & 140,1 & 89,76 & 14,4 & 2,46 & 0,22 & 0,35 & 1,02 & 0,80 & 8,79 & 32,26 & 173,4 & 226,7 \\
\hline 20 & $x$ & 53,79 & 76,49 & 90,1 & 98,63 & 99,6 & 99,8 & 99,5 & 99,26 & 95,64 & 81,44 & 68,74 & 47,10 \\
\hline 21 & $\%$ & $0 \%$ & $0 \%$ & $0 \%$ & $19 \%$ & $32 \%$ & $46 \%$ & $44 \%$ & $31 \%$ & $0 \%$ & $0 \%$ & $0 \%$ & $0 \%$ \\
\hline 21 & $\mathrm{~s}^{2}$ & 264,3 & 471,6 & 448 & 207,3 & 51,5 & 37,4 & 99,9 & 119,2 & 369,0 & 505,4 & 437,8 & 263,2 \\
\hline 21 & $x$ & 39,91 & 57,40 & 74,3 & 88,87 & 95,6 & 95,7 & 93,2 & 92,70 & 82,17 & 63,47 & 50,98 & 33,94 \\
\hline 22 & $\%$ & $0 \%$ & $0 \%$ & $0 \%$ & $24 \%$ & $39 \%$ & $55 \%$ & $49 \%$ & $33 \%$ & $0 \%$ & $0 \%$ & $0 \%$ & $0 \%$ \\
\hline 22 & $\mathrm{~s}^{2}$ & 291,5 & 414,3 & 177 & 56,29 & 7,81 & 12,3 & 24,8 & 24,67 & 117,2 & 275,5 & 468,7 & 255,3 \\
\hline 22 & $x$ & 42,25 & 62,08 & 80,6 & 93,68 & 97,8 & 97,7 & 96,5 & 96,14 & \begin{tabular}{|l|}
88,25 \\
\end{tabular} & 70,00 & 54,22 & 37,34 \\
\hline 23 & $\%$ & $0 \%$ & $0 \%$ & $0 \%$ & $31 \%$ & $46 \%$ & $62 \%$ & $59 \%$ & $38 \%$ & $0 \%$ & $0 \%$ & $0 \%$ & $0 \%$ \\
\hline 23 & $\mathrm{~s}^{2}$ & 264,4 & 275,6 & 100 & 19,78 & 2,51 & 2,27 & 7,71 & 6,70 & 59,38 & 160,6 & 361,0 & 288,0 \\
\hline 23 & $x$ & 45,42 & 67,08 & 84,2 & 96,20 & 98,8 & 98,9 & 98,1 & 97,83 & 91,38 & 74,31 & 58,93 & 39,16 \\
\hline 24 & $\%$ & $0 \%$ & $0 \%$ & $0 \%$ & $34 \%$ & $52 \%$ & $72 \%$ & $64 \%$ & $46 \%$ & $0 \%$ & $0 \%$ & $0 \%$ & $0 \%$ \\
\hline 24 & $\mathrm{~s}^{2}$ & 206,2 & 188,8 & 55,4 & 8,44 & 0,65 & 1,08 & 2,29 & 2,70 & 26,11 & 91,17 & 286,8 & 265,5 \\
\hline 24 & $x$ & 48,78 & 70,97 & 86,9 & 97,39 & 99,3 & 99,3 & 98,9 & 98,59 & 93,58 & 77,51 & 62,64 & 42,10 \\
\hline 25 & $\%$ & $0 \%$ & $0 \%$ & $0 \%$ & $39 \%$ & $60 \%$ & $80 \%$ & $74 \%$ & $51 \%$ & $0 \%$ & $0 \%$ & $0 \%$ & $0 \%$ \\
\hline
\end{tabular}




\begin{tabular}{|c|c|c|c|c|c|c|c|c|c|c|c|c|c|}
\hline No, & Result & \multicolumn{10}{|c|}{ MONTHS } \\
\hline 25 & $\mathrm{~s}^{2}$ & 171,1 & 136,5 & 27,3 & 4,32 & 0,41 & 0,58 & 1,54 & 1,53 & 12,92 & 52,67 & 225,9 & 241,2 \\
\hline 25 & $\mathrm{X}$ & 51,49 & 73,95 & 88,8 & 98,14 & 99,5 & 99,6 & 99,2 & 98,97 & 94,90 & 79,79 & 65,89 & 44,87 \\
\hline
\end{tabular}

\section{CONCLUSION}

The definition of sustainable development assumes working out such mechanisms and ways of acting which will allow to continue the further civilization development while maintaining the laws of nature and socio-economic aspirations of mankind (Skowroński A., 2006. p. 50). In the field of architecture and civil engineering, the term can be applied to activities aimed at reducing the negative impact of construction projects on the environment. As an example of such actions one can take as an example already visible trends of reducing energy consumption in designed objects, as well as adequate modernization of already existing buildings. At the stage of investment decision, factors influencing operating costs are analysed, such as building location, cubic capacity or interior layout. Enabling designers already at the stage of shaping the architectural concept to make informed decisions about maximizing the impact of natural lighting on the quality of the implemented interiors will positively affect the economics of the design process. The example cited in the paper of using artificial neural networks demonstrates further possibilities of adapting the technology for the purposes of efficiency and ergonomics of design. Carried out simulations have shown the impossibility of limiting themselves only to the use of natural lighting in office buildings located in Poland (Table 1), assuming that they will be used in year-round mode. It was shown that in the Polish climate, it is necessary to use additional solutions to provide natural lighting or artificial lighting, taking into account that the external partitions may have an individual character, so the area of glazing will be smaller, or there may be adjacent buildings partially blocking the light source. The study focused on the determination of the intensity of natural light, while the influence of thermal comfort on the perceived quality of space was omitted.

\section{EFEKTYWNOŚĆ NATURALNEGO OŚWIETLENIA BUDYNKÓW BIUROWYCH NA PRZYKŁADZIE OBIEKTU ZLOKALIZOWANEGO W POLSCE}

\section{WSTĘP}

Współczesne koncepcje projektowania budynków dążą do ograniczenia negatywnego wpływu realizacji tych inwestycji na środowisko naturalne. W 2018 roku Komisja Europejska opublikowała długofalową strategię, której celem jest uzyskanie neutralności klimatycznej (Komisja Europejska, 2018), co przyczyniło się do zwiększenia nakładów pracy w kierunku redukcji niekorzystnego oddziaływania w sektorze inżynierii lądowej. W literaturze przedmiotu można odnaleźć wyraźny podział sposobów uzyskania zmniejszenia negatywnego wpływu na środowisko tj. na aktywne i pasywne. Do pierwszej grupy zaliczyć można rozwiązania takie jak m.in. pompy ciepła (Kimata S., 
Shina T., Sato T., Tokoro K., 2020.), natomiast przykładem rozwiązania zaliczanego do drugiej kategorii mogą być np. systemy przesłaniania okien (Kunwar N., Bhandari M., 2020).

Zapotrzebowanie energetyczne budynku zależy w głównej mierze od lokalizacji, klimatu, pory roku oraz sposobu użytkowania obiektu, natomiast sama energia wykorzystywana jest m.in. do wentylacji, ogrzewania, chłodzenia oraz oświetlenia (Sassi P., 2006, p. 205). Raport firmy Knight Frank opierając się na uzyskanych danych z lat 2011-2018 wykazał, że zużycie mediów w budynkach komercyjnych pochłania 37\% całości kosztów eksploatacyjnych (Knight Frank, 2019, p. 5), przez co istotnym z punktu widzenia zrównoważonego rozwoju jest szukanie efektywnych sposobów na minimalizowanie potrzebnej energii zarówno ze względów ekonomicznych jak i środowiskowych.

Jakością oświetlenia naturalnego zajmowali się m.in. Dariusz Masły oraz Michał Sitek(Masły D., Sitek M., 2013.). Autorzy w swoim opracowaniu podjęli temat wpływu rozwiązań elewacyjnych na natężenie światła dziennego, przy uwzględnieniu zjawisku przegrzania przestrzeni. Współczesne tendencje badawcze w dużej mierze oscylują wokół rozwoju sposobów pozwalających na zwiększenie ilości naturalnego oświetlenia. Koncepcja wykorzystania atrium jako dodatkowego doświetlającego źródła było badane przez liczne zespoły badawcze (Rastegari M., Pournaseri S., Sanaieian H., 2021., Fan Z., Yang Z., Yang L., 2021., Ferreira T, Bournas I, Dubois M-C, 2019., SusaPáez A., Piderit-Moreno M. B., 2020. ), lecz takie rozwiązanie znajduje zastosowanie praktycznie jedynie w projektowaniu nowych budynków. Istnieją także analizy, w których wykorzystano sztuczne sieci neuronowe do przewidywania naturalnego oświetlenie wewnątrz budynku (Walger da Fonseca R., Didoné E. L., Pereira F. O. R., 2013.) Jedną z ważniejszych decyzji podczas procesu projektowania przestrzeni biurowych jest określenie sposobu doświetlenia przestrzeni. Powinno zostać zapewnione oświetlenie w sposób naturalny oraz sztuczny. Istotą zagadnienia jest zaprojektowanie przeszkleń w sposób jak najbardziej efektywny biorąc pod uwagę takie parametry jak ilość dostępu światła naturalnego, ograniczenie zjawiska przegrzewania wnętrz czy efektywność ekonomiczna zastosowanych rozwiązań. Do sposobów doświetlenia naturalnego można zaliczyć ingerencję $w$ bryłę budynku np. poprzez zastosowanie przeszklonego atrium lub rozwiązania doraźne jak np. wykorzystanie tzw. półek świetlnych.

Pomimo istnienia pojedynczych sposobów na zwiększenie ilości naturalnego światła, brakuje jednoznacznych wyników badań określających efektywność nasłonecznienie naturalnego w obrębie układów biurowych znajdujących się na terenie Polski. W niniejszej pracy przeprowadzono, w związku z tym analizę iteracyjną, której głównym celem była weryfikacja możliwości stosowania układów biurowych bez sztucznych źródeł światła. Interpretacja otrzymanych wyników usprawni proces projektowy pod względem szacowania zapotrzebowania na dodatkowe źródła światła. Dane dotyczące efektywności naturalnego oświetlenia mogą zostać wykorzystane przy projektowaniu nowych budynków, lub podczas oceny możliwości wykorzystania już istniejących obiektów na cele biurowe.

\section{EWOLUCJA PRZESTRZENI BIUROWYCH}

W swojej publikacji z 1997 roku Elżbieta Niezabitowska podzieliła historię rozwoju obiektów biurowych na sześć zasadniczych okresów (Niezabitowska E., 1997, p. 42). Pierwszy okres autorka utożsamia z istnieniem tzw. Buleuterionu w starożytnej Grecji, który później stanowił pierwowzór średniowiecznych ratuszy. Kolejny okres odniesiony został do czasów od powstania pierwszego średniowiecznego włoskiego ratusza aż do XIX wieku, w którym to rozdzielono funkcję administracyjne od sądowniczych i bankowych. Trzeci okres nawiązuje do tzw. szkoły chicagowskiej w drugiej połowie XIX wieku. Kolejny okres trwał do lat 50-tych XX wieku, w którym wykształciły się wielkoprzestrzenne budynki biurowe. W piątym etapie charakterystycznym wykorzystywanym zabiegiem było krajobrazowe rozwiązywanie wnętrz obiektów biurowych. Ostatni etap rozpoczął się w latach 70-tych XX wieku, w którym zaobserwowano zwiększone zapotrzebowanie na tzw. wysoko kwalifikowaną pracę biurową wraz z wprowadzeniem do przestrzeni biurowych komputerów. Przełom w kształtowaniu budynków biurowych związany jest z coraz częściej stosowanym rozwiązaniem obiektów o konstrukcji szkieletowej. Jednym z budynków, którego funkcję i formę utożsamić można z współczesnymi rozwiązaniami biurowymi był The Home Insurance Building zrealizo- 
wany w 1885 roku (Moon K. S., 2018, p. 2). Koncepcja teorii organizacji pracy F.W Taylora zakładająca zwiększenie efektywności pracy m.in. poprzez podział pracy na etapy, motywowanie pracowników bodźcami finansowymi czy eliminacja rozpraszających elementów została zawarta w realizacji Larkin Building z 1904 roku autorstwa Franka Lloyda Wrighta (Urbanowicz B., 2011, p. 55). W budynku zaprojektowano współną przestrzeń z biurkami dla pracowników ułożonych w szyku z małymi odległościami, podczas gdy kierownictwu zapewniono pomieszczenia indywidualne ułożone wzdłuż wewnętrznych ścian. Rozwinięcie takiego układu można odnaleźć we współczesnych realizacjach. Adam Dzidowski charakteryzując zmiany w przestrzeni biurowej zwrócił uwagę na zmianę w kształtowaniu się podejścia do organizacji pracy (Dzidowski A., 2015, p.159). Autor wyszczególnił pięć koncepcji, wpływających na zmianę przestrzeni biurowych. Pierwszy „Tayloryzm” zakładał zwrócenie szczególnej uwagi m.in. na ekonomię ruchu, sprawność i systemowość pracy. „Bürolandschaf” występujący w drugiej połowie XX wieku uwzględniał wolność i prywatność jednocześnie podkreślając konieczność mechanizacji i systemowości pracy. „Action Office" datowany przez autora na rok 1968 charakteryzował się dążeniem do wykorzystywania modularnych sześciennych form w celu wyodrębnienia przestrzeni. „Cube Farm” występujący ok. 1980 roku stanowił rozwinięcie wcześniejszej formy ze zmianą funkcji kubicznych form, które w tej koncepcji pełniły funkcje dyscyplinujące. Ostatni wymieniony przez badacza system pracy określił jako „Networking”, który skupia się na mobilności i informatyzacji. Maciej Złowodzki w publikacji z 2008 roku scharakteryzował polski rynek obiektów biurowych (Złowodzki M., 2008, p.75-77). Autor zwrócił szczególną uwagę na problemy rozwiązań zarówno na poziomie architektonicznym jak i urbanistycznym budynków o funkcji biurowej m.in. nieład przestrzenny czy standardy odbiegające od tożsamych obiektów Europy Zachodniej. Badacz punktuje zaniechania w braku opracowań spójnych programów badawczych oraz niewyciągania doświadczeń z innych krajów.

\section{METODYKA BADAŃ}

Zgodnie z obowiązującą normą określającą warunki oświetlenia miejsc pracy dla m.in pokoi konferencyjnych, pokoi spotkań czy stanowisk pracy CAD minimalne natężenie oświetlenia wynosi 500 Ix (PN-EN 12464-1, s.30). Metody analizy oświetlenia wnętrz można podzielić na dwa główne podejścia. Pierwsze z nich polega na wykorzystaniu danych rzeczywistych uzyskanych z rozstawionych fizycznie czujników. które rejestrują poziom natężenia światła i jego zmiany w czasie, co stanowi podstawę do stworzenia modelu. Natomiast druga metoda, wykorzystana w niniejszej publikacji, polega na przewidywaniu poziomu natężenia światła w określonych warunkach przy wykorzystaniu symulacji komputerowej. Model badawczy przygotowano z wykorzystaniem oprogramowania Rhino z nakładką do modelowania parametrycznego Grasshopper. W celu przeprowadzenia symulacji pozwalającej określić natężenie światła naturalnego dla przyjętych geometrii wykorzystano dodatek Honeybee bazujący na wynikach uzyskanych z oprogramowania Daysim, które umożliwiły na podstawie przyjętej siatki określić procentowy czas wymaganego nasłonecznienia w badanym zakresie (Fig.1).

Badano efektywność naturalnego oświetlenia kondygnacji obiektu biurowego zrealizowanego w układzie liniowym zgodnym z typologią zaproponowaną przez Annę Taczalską (Taczalska A., 2016, p. 27). Dla potrzeb symulacji przyjęto standardowy czas pracy budynków biurowych tj. od stycznia do grudnia w godzinach 8 do 16 .

W celu porównania zależności pomiędzy wysokością a głębokością kondygnacji wykorzystano algorytm iterujący Colibri 1.0. Bazując na stosowanych rozwiązaniach konstrukcyjnych w budownictwie dla badanej symulacji przyjęto następujące wartości zmienne (Fig. 2):

- wysokość kondygnacji w zakresie $3.0 \mathrm{~m}$ do $5.0 \mathrm{~m}$;

- głębokość kondygnacji od $5.0 \mathrm{~m}$ do $9.0 \mathrm{~m}$.

Wykonano indywidualne odczyty podzielone na poszczególne miesiące dla przyjętej lokalizacji tj. Warszawy. W przeprowadzonej symulacji założono pełne szklenie przegród zewnętrznych. Obszar badawczy został podzielony na kwadraty o boku $1 \mathrm{~m}$. Uzyskane zbiorcze wyniki przedstawiono na rycinie 3 . 


\section{UZYSKANE WYNIKI}

W ramach przeprowadzonego badania uzyskano różne podziały siatek, ze względu na wartość parametru głębokości kondygnacji tj. podział wyniósł kolejno 363 pola dla $5.0 \mathrm{~m}, 433$ pola dla $6.0 \mathrm{~m}$, 553 pola dla $7.0 \mathrm{~m}, 643$ pola dla $8.0 \mathrm{~m}, 757$ pola dla $9.0 \mathrm{~m}$. W celu łatwiejszej interpretacji otrzymanych wyników przygotowano zbiorczą tabelkę przedstawiającą ilość pól, które przez cały zakładany okres badawczy otrzymuje natężenie $500 \mathrm{Ix}$ wyrażoną w procentach, wartość średniej (oznaczona symbolem „X”) i wariancji (oznaczona symbolem „,2”) dla każdego badanego układu w danym miesiącu (Tab.1). Interpretując parametr określający ilość pól otrzymujących wymaganą wartość natężenie światła określoną przez PN-EN 12464-1 wnioskuje się, że żaden z analizowanych układów w ciągu roku nie zapewnia wymaganego oświetlenia wykorzystując naturalne źródła światła. Najlepsze rezultaty uzyskano w miesiącu czerwcu dla układów 9 i 10, oraz w lipcu dla układu 10 tj. uzyskano minimum 500 Ix przez cały miesiąc w godzinach od 8 do 16 . Najmniej optymalne wyniki pod względem procentowego czasu zapewnienia minimalnej wartości natężenia światła uzyskały układy numer 16 oraz 21. Najmniejsze i jednocześnie najbardziej zbliżone do siebie wartości wariancji występują w układach 3-5 oraz 8-10, natomiast największe wartości średnich, w których występują najmniejsze wahania odczytów w ciągu badanego roku to układy 5 i 10, przez co wnioskuje się, że ze wszystkich badanych wariantów układy 5 i 10 są najbardziej optymalne pod względem ilości naturalnego nasłonecznienia. Największe wartości wariancji uzyskano dla układów 1617 oraz 21-22, podczas gdy najmniejsze wartości średnich odczytać można dla układu 16 i 21, które to warianty są najbardziej niekorzystne. Najlepsze wyniki uzyskano dla parametrów wysokości i głębokości $5.0 \mathrm{~m}$ i $5.0 \mathrm{~m}$ oraz $5.0 \mathrm{~m} \mathrm{i} 6.0 \mathrm{~m}$, natomiast najbardziej niekorzystne wyniki uzyskano dla wartości wysokości i głębokości wynoszących kolejno $3.0 \mathrm{~m}$ i $8.0 \mathrm{~m}$ oraz $3.0 \mathrm{~m}$ i 9.0m (Ryc. 4). Równie istotną informacją jest zupełny brak pól spełniających założony warunek w miesiącach od stycznia do marca i od września do grudnia wynikające z przyjętej lokalizacji, co przekłada się na konieczność zapewnienia dodatkowego oświetlenia sztucznego w budynkach biurowych znajdujących się na terenie Polski, przy założeniu całorocznego wykorzystywania takich budynków.

\section{WNIOSKI}

Definicja zrównoważonego rozwoju zakłada wypracowanie takich mechanizmów i sposobów działania, które pozwolą kontynuować dalszy rozwój cywilizacyjny z zachowaniem praw przyrody i społeczno-gospodarczych aspiracji ludzkości (Skowroński A., 2006. p. 50). W dziedzinie architektury i inżynierii lądowej przedstawiony termin odnieść można do działań mających na celu zmniejszenie negatywnego oddziaływania inwestycji budowlanych na środowisko. Jako przykład takich działań przyjąć można widoczne już trendy ograniczania zużycia energii w obiektach projektowanych, jak również odpowiednią modernizację budynków już istniejących. Na etapie decyzji inwestycyjnej analizowane są czynniki wpływające na koszty eksploatacyjne jak np. lokalizacja obiektu, kubatura czy układ wnętrz. Umożliwienie projektantom już na etapie kształtowania koncepcji architektonicznej podejmowania świadomych decyzji w zakresie zmaksymalizowania wpływu naturalnego oświetlenia na jakość realizowanych wnętrz wpłynie pozytywnie na ekonomikę procesu projektowego. Przytoczony w tekście przykład wykorzystania sztucznych sieci neuronowych świadczy o dalszych możliwościach adaptowania technologii dla celów efektywności i ergonomii projektowania. Przeprowadzone symulacje wykazały brak możliwości ograniczenia się jedynie do stosowania nasłonecznienia naturalnego w obiektach biurowych zlokalizowanych w Polsce (Tab. 1), przy założeniu, że będą one wykorzystywane w trybie całorocznym. Wykazano, że w klimacie polskim konieczne jest stosowanie dodatkowych rozwiązań zapewniających naturalne oświetlenie lub sztuczne oświetlenie biorąc poprawkę na to, że przegrody zewnętrze mogą mieć indywidualny charakter przez co powierzchnia szklenia będzie mniejsza lub mogą występować budynki sąsiednie częściowo zabierające źródło światła. Przeprowadzone badania skupiły się na określeniu natężenia światła naturalnego, podczas gdy pominięty został wpływ komfortu cieplnego na odczuwalną jakość przestrzeni. 


\section{BIBLIOGRAPHY}

Dzidowski A., 2015., Architektura organizacyjna. Pomiędzy strukturą a przestrzenią organizacji, Rocznik Lubuski, tom 41, p. 159

Fan Z., Yang Z., Yang L., 2021. Daylight performance assessment of atrium skylight with integrated semitransparent photovoltaic for different climate zones in China, Building and Environment 190

Ferreira T, Bournas I, Dubois M-C, 2019. Effect of atrium geometry and reflectance on daylighting in adjacent rooms, Journal of Physics: Conference Series 1343

Kimata S., Shina T., Sato T., Tokoro K., 2020. Operation planning for heat pump in a residential building, Journal of Advanced Mechanical Design, Systems, and Manufacturing Vol. 14, No. 5

Knight Frank, 2019., Koszty i połaty eksloatacyjne w budynkach biurowych w latach 2011-2018

Komisja Europejska, Neutralność klimatyczna do 2050r., 2018r. https://op.europa.eu/pl/publication-detail//publication/92f6d5bc-76bc-11e9-9f05-01aa75ed71a1, access 2021.05.15

Kunwar N., Bhandari M., 2020., A Comprehensive Analysis of Energy and Daylighting Impact of Window Shading Systems and Control Strategies on Commercial Buildings in the United States, Energies

Masły D., Sitek M., 2013., Zastosowanie symulacji komputerowych do analizy wpływu rozwiązań elewacyjnych na jakość oświetlenia naturalnego w biurowcach, Kierunki rozwoju budownictwa energooszczędnego i wykorzystania odnawialnych źródeł energii na terenie Dolnego Śląska, Oficyna Wydawnicza Politechniki Wrocławskiej, p. 121-134

Moon K. S., 2018., Dynamic Interrelationship between the Evolution of Structural Systems and Facade Design in Tall Buildings: From the Home Insurance Building in Chicago to the Present, International Journal of High-Rise Buildings, Vol 7, p. 2

Niezabitowska E., 1997., Projektowanie obiektów biurowych. Cz. 1 ; Historia. Rodzaje obiektów biurowych, Wydawnictwo Politechniki Śląskiej, p. 42

PN-EN 12464-1 Światło i oświetlenie. Oświetlenie miejsc pracy. Część 1: Miejsca pracy we wnętrzach, p. 30

Rastegari M., Pournaseri S., Sanaieian H., 2021. Daylight optimization through architectural aspects in an office building atrium in Tehran, Journal of Building Engineering, p. 33

Sassi P., 2006., Strategies for Sustainable Architecture, Taylor \& Francis

Skowroński A., 2006. Zrównoważony rozwój perspektywą dalszego postępu cywilizacyjnego, Problemy Ekorozwoju vol 1 No 2, p. 50

Susa-Páez A., Piderit-Moreno M. B., 2020. Geometric Optimization of Atriums with Natural, Lighting Potential for Detached High-Rise Buildings, Sustainability

Taczalska A., 2016., Architektura współszesnych budynków biurowych w Polsce, ze szczególnym uwzględnieniem Krakowa i Warszawy. Aspekt środowiska miejsc pracy na tle tendencji europejskich. Dysertacja doktorska wykonana na Wydziale Architektury Politechniki Krakowskiej

Urbanowicz B., 2011., Wpływ torii organizacji pracy na przestrzeń biurową, Architecturae et Artibus 4/2011, p. 55

Walger da Fonseca R., Didoné E. L., Pereira F. O. R., 2013., Using artificial neural networks to predict the impact of daylighting on building final electric energy requirements., Energy and Buildings, p. 31-38

Złowodzki M., 2008., Współczesne biura - rola, forma i przestrzeń aktywności, Kwartalnik Architektury i Urbanistyki 3/2008, p. 64-81.

\section{AUTHOR'S NOTE}

Since 2017 he has been professionally associated with the Rzeszów University of Technology. Graduated in Architecture and Urban Planning and Construction. In his scientific work he deals with the use of parametric modeling tools in the field of Architecture and Construction solutions, both in the design and research context. 


\section{O AUTORZE}

Od 2017 roku związany zawodowo z Politechniką Rzeszowską. Absolwent kierunku Architektura i Urbanistyka oraz Budownictwo. W pracy naukowej zajmuje się wykorzystaniem narzędzi modelowania parametrycznego w rozwiązaniach z dziedziny Architektury i Budownictwa, zarówno w kontekście projektowym jak i badawczym.

Contact | Kontakt: r.licholai@prz.edu.pl 